Thouraya Messallam Hassan, Mohamed Samir El-Dashlouty, and Mona Mohammad

\title{
THE EFFECT OF DIETARY HABITS AND LIFESTYLE ON GASTROINTESTINAL, LIVER, AND KIDNEY CLINICAL STATUS IN UNIVERSITY HOSTEL STUDENTS
}

\section{Thouraya Messallam Hassan, Mohamed Samir El-Dashlouty, and} Mona Mohammad Salama

Department of Nutrition and Food Sci., Faculty of Home Economics, Menoufia Univ.,Shebin El-Kom,Egypt

\begin{abstract}
7 his study was conducted to investigate the effect of college hostels residents' life style and eating habits and their impact on liver, kidneys

1 and gastro intestinal system (GIT), and to compare between girls and boys inside the hostels concerning the same parameters. The study started by giving several questionnaires to elicit their general complaints and detailed symptoms, after which anthropometric measures were taken then clinical examinations and laboratory investigations were carried out. The study tried to detect the most prevailing GIT, liver and kidneys diseases that affected students in university hostels. Recommendations to solve these complaints were presented. The study found that college students in the university hostels practiced unhealthy life style and food habits; 53\% ate while watching TV, 8\% of boys are cigarette smokers, the frequency of sports per week was as low as 1.2 times only, $70 \%$ of students preferred junk foods and $45 \%$ of students preferred fried foods. These habits affected the GIT negatively as the most prevalent general complaint was pain, food allergies and infestations. $81.7 \%$ of all students had troubles of GIT, $83.4 \%$ of girls and $80 \%$ of boys. Students were then clinically examined and samples were drawn for laboratory tests. Clinical examination showed prevalence of GIT signs (72\%).
\end{abstract}

Key words: Gastro intestinal system, GIT, liver, hepatic, kidneys, renal, loin, college students, hostels. 
Thouraya Messallam Hassan, Mohamed Samir El-Dashlouty, and Mona Mohammad

Salama

INTRODUCTION

Students living in university hostels are a distinct group of university students who have unique needs and problems. They have particular physical, social and emotional characteristics. University students are mature, and also understand the importance of good diet but mostly they ignore proper food and diet. Essential nutrients like essential amino acids, fat, vitamins and minerals are not only compulsory compounds for survival but these are very essential for study to achieve the goals (Aravind $\boldsymbol{e t}$ al., 2011).

In all the countries for the higher education most of the students live in hostels or campus, where hostel life has strong impact on the health (Elkhalifa et al., 2000). Balanced and adequate nutrition is important to maintain good health and quality of life. Even a single nutrient can cause different disorders in human body (Memis and Sanlier, 2010).

Doygun and Gulec (2012) reported that university students faced lot of problems, along with the choice of the right food according to their health and body requirement.

Most university student did not meet the recommended intakes for most of the macronutrient and micronutrient (Sanlier and Unusan, 2007). The prevalence of underweight among female students is higher than male students (Huda and Ruzita, 2011).

The study of Abolfotouh et al., (2007) reported that college students tend to practice poor eating habits for instance skipping meals, low frequency of vegetables, fruits and fish consumption, prefer to fatty food and poor physical activity. Globally, there has been an increased intake of energy-dense foods that are high in fat, salt and sugars but low in vitamins, 
The Effect of Dietary Habits and Lifestyle on Gastrointestinal, Liver, and Kidney Clinical Status in University Hostel Students

Thouraya Messallam Hassan, Mohamed Samir El-Dashlouty, and Mona Mohammad Salama

minerals and other micronutrients (WHO, 2011). Meal and snacking patterns have been shown to give effects on body weight cognition, cardiovascular outcomes, lipid profiles and carbohydrate tolerance (Ma et al., 2003 and Song et al., 2005).

Diet and nutrition contribute appreciably to the burden of chronic and preventable diseases; such as obesity, cardiovascular disease, diabetes, and many cancers. When university students make positive changes in exercise and dietary habits, and when these changes persist into the adult years, the risk of chronic diseases may be reduced (Folake et.al. 2016)

\section{SUBJECTS \& METHODS}

Sixty college students from Shebin El Kome University hostels- Menoufia governorate were chosen. A total numbers of 30 females and 30 males, 17-21 years of age. Only those who agreed to give a blood sample were enrolled in the study. Students were examined through a multi- leveled study; structured interviewing questionnaires, clinical examination, laboratory investigations and food analysis.

The first questionnaire included personal (name, sex, age) and educational level plus life style (sleeping hours, engagement in sports and their number per week, watching TV and number of hours, eating while watching TV, feeling nervous or irritable, smoking cigarettes and number per day, and feeling lethargic and less vital.

The second questionnaire included general complaint, and health-related nutritional history, family history concerning obesity, leanness, colitis, spastic colon), symptoms denoting liver and kidneys affection, and lastly history of gastrointestinal tract troubles.

The third questionnaire revealed some food habits; e.g. fast foods and type of cooking (boiled, grilled, and fried). 
The Effect of Dietary Habits and Lifestyle on Gastrointestinal, Liver, and Kidney

Clinical Status in University Hostel Students

Thouraya Messallam Hassan, Mohamed Samir El-Dashlouty, and Mona Mohammad

Salama

The anthropometric data; height (cms), weight $(\mathrm{kg})$ and body mass index (weight in $\mathrm{kg} /$ height $^{2}$ in meters) were measured for all students.

Then students were clinically examined for GIT, liver and kidneys signs (tongue, gums, abdominal tenderness, distension, loin tenderness, liver enlargement).

Laboratory investigations were done, where blood samples were drawn from all students which were then examined for:

Hemoglobin concentration

Hemoglobin

determination carried out according to the method of

Dacie and Lewis (1998).

Random sugar;

Blood Glucose was determined according to

Kaplan (1984).

Lipid profile (HDL-C LDL-Cand triglycerides);

Triglyceride in serum was calorimetrically

determined according to

Fossati and Prencipe (1982).Total cholesterol was determined by

colorimetric method according to Allain et al., (1974). Determination of HDL-C was carried out according to the method of Lopez (1977) and LDL-C in $\mathrm{mg} / \mathrm{dl}$, according to Friedewald et. al. (1972) LDL cholesterol=Total Cholesterol-(HDLT.G/5)mg/dl.

Liver function tests (SGPTSGOT);

Determination of serum AST activity was measured by method of Yound (1975) and ALT activity was measured by method of Tietz (1976).

Kidney function tests (urea, creatinine, uric acid);

Enzymatic determination of serum urea was carried out according to the method of Malhotra (2003). Serum creatinine is determined by kinetic method according to Henry et al., (1974) and uric acid by enzymatic test 
The Effect of Dietary Habits and Lifestyle on Gastrointestinal, Liver, and Kidney Clinical Status in University Hostel Students

Thouraya Messallam Hassan, Mohamed Samir El-Dashlouty, and Mona Mohammad

Salama

using kits according to

Scheibe et al., (1974).

\section{Statistical analysis}

All test data was converted and manipulated by using SPSS software program version 18.0. Data was analyzed, mean and standard deviation was calculated as regarding quantitative data as number of fast food per week and biochemical data while qualitative data as faculty, type of study, type of fast food presence of allergic symptoms and general complain were presented by number and percent. Comparisons between boys and girls were done. The quantitative data was compared and $t$ test was applied and $p$ value was established to determine the statistically significant difference between two groups. While Chi Square was calculated among groups as regards qualitative data. Odds ratio and $95 \%$ confidence interval were computed. The difference between the two groups were considered statistically significant when $\mathrm{p}<0.05$, and considered highly statistical significant when $\mathrm{p}<0.01$ (Artimage and Berry, 1987).

\section{RESULTS \& DISCUSSION}

\section{Demographic, personal results and family history}

Data presented in table (1) show the demographic information of 60 students aged from 17 to 21 years. More than half of the male students $(53.3 \%)$ were enrolled in the Faculty of Engineering and (20\%) were students in the Faculty of Medicine, while more than half of the female students (53.3\%) were students in Faculty of Home Economies. In general 41.7\% were students in Home economies, (26.7) \% in Engineering, (10\%) in Medicine and $(10 \%)$ in the faculty of Law, i.e. $78.3 \%$ practical colleges and $21.7 \%$ theoretical section.

The anthropometric measurements and the body mass index of the students are 
The Effect of Dietary Habits and Lifestyle on Gastrointestinal, Liver, and Kidney Clinical Status in University Hostel Students

Thouraya Messallam Hassan, Mohamed Samir El-Dashlouty, and Mona Mohammad Salama

shown in (Table 2). The mean ages of male and female students were significantly different (19.4 \pm 0.8$)$ years and $(18.4 \pm 1.4)$ years respectively $(\mathrm{p}<0.001)$ and the mean age of both sexes was (18.9 \pm 1.2 years).

Male students had significantly higher body weight $(81.9 \pm 11.9 \mathrm{~kg})$ than female students $(65.2 \pm 13.5 \mathrm{~kg}) \quad(\mathrm{p}$ $<0.001)$. The mean height of male students $(177.3 \pm 5.6 \mathrm{~cm})$ was significantly higher than female students $(160.9 \pm 7.1 \mathrm{~cm})$ $(\mathrm{p}<0.001)$.

The mean body mass index of boys $(26.0 \pm 3.2)$ is higher than that of girls (25.2 \pm 5.2$)$. Both means lie within the overweight zone (26.0 \pm 3.2$)$ according to WHO (2007) for 19 years old boys and girls who stated that the overweight zone for boys and girls is (25.6 ---29) and (25.1--29) respectively.

\section{Life style and food habits}

The sleeping hours for subjects of our study (Table 3 ) were marginal $(7.4 \pm 1.4)$ according to the National Sleep Foundation (2015) that presented new recommendations:

- Teenagers (14-17 years): Sleep range widened by one hour to 8-10 hours (previously it was 8.5-9.5)

- Adults (18-25 years): Sleep range is 7-9 hours (new age category)

In this study $(63.3 \%)$ of boys were engaged in sport compared to $(30 \%)$ of girls, however the frequency of sport per week was similar $(1.2 \pm 1.2)$ for both and far below normal according to the fact sheet issued by the WHO (2016) which reported that the physical activity should be as follows:

17 years old should at least do a 60 minutes of moderate- to vigorous-intensity physical activity daily and (1821 years old, should do at least 150 minutes of moderateintensity aerobic physical activity throughout the week. 
The Effect of Dietary Habits and Lifestyle on Gastrointestinal, Liver, and Kidney

Clinical Status in University Hostel Students

Thouraya Messallam Hassan, Mohamed Samir El-Dashlouty, and Mona Mohammad

Salama

Boys spend (1.7 $\pm 1.4 \mathrm{hrs})$ watching TV, $53 \%$ of boys eat while watching $\mathrm{TV}$, while girls spend $(2.0 \pm 1.6 \mathrm{hrs})$ watching $\mathrm{TV}, 60 \%$ of girls eat while watching TV.

USDL (2016) recent statistics reported that for ages of 15 and over, they watched traditional TV on an average of 2.8 hours per day among Americans.

None of the girls was reported smoking cigarettes, while $8 \%$ of boys are smokers and the mean number of cigarettes was $3.2 \pm 8.1$ per day.

\section{According to Centers}

for Disease Control and Prevention, (2015) nearly 17 of every 100 U.S. adults aged 1824 years or older (16.8\%) smoked cigarettes. More than 16 million Americans live with a smoking-related disease.

The difference between this study and the results of the Americans may be due to the fact the majority of girls in Egypt refrain from smoking and it may be also due to financial reasons.

Comparison between boys and girls students according to fast foods consumed:

$70 \%$ of all students (Table 4) ate fast foods; $80 \%$ of boys and $60 \%$ of girls. $30 \%$ had restrained from eating fast foods; girls were more aware of its hazards; $40 \%$ of girls had no fast foods while only $20 \%$ of boys had no fast foods. Number of meals eaten as fast foods by boys per week was also more than girls; $3.3 \pm 5.2$ and $1.7 \pm 2.0$ respectively. However, students differed in their preference to the type of fast foods.

The first group (Fig1) (Hawawshi, Kofta Shawerma and Burger) were eaten 22 times per week by all students and these were the preferred food. Chicken, Kentucky and Pane sandwiches come in rank 2 and students ate them 20 times per week. Pizza, Pies and Kreps were their third choice and were eaten by all students 17 times per week. Then Koshari 16 times 
The Effect of Dietary Habits and Lifestyle on Gastrointestinal, Liver, and Kidney

Clinical Status in University Hostel Students

Thouraya Messallam Hassan, Mohamed Samir El-Dashlouty, and Mona Mohammad

Salama

per week, followed by Foul and Falafel 15 times per week, then Potatoes Chips 12 times per week. Macaroni and Luncheon came last; 8 and 6 times per week respectively.

Junk food is an anomaly when it comes to historical traditions of cuisine. It emerges in the context of youth culture in America in the model part of the twentieth century but soon turns into a type of food eaten by people of any age (Marcel, 2016).

In a study done in London high schools, Carahera et al., (2016) reported that there were concentrations of food outlets around the schools. The majority of pupils' food purchases were from small local shops and supermarkets of chocolate, crisps (potato chips), fizzy drinks and energy drinks. Availability of fast food and unhealthy options were a feature of the streets surrounding the schools. Pupils reported healthy items on sale in school as expensive, and was not seen as cool.

Campos et al., (2016) concluded that Broadcasting of unhealthy TV food advertising puts children and adolescent in risky health hazards although it had decreased due to the new European and Spanish Public Health laws published in 2011.

\section{Preferable method of meat cooking for students:}

$55 \%$ of students preferred frying different types of meats, $38 \%$ prefer grilled meats and only $10 \%$ prefer the healthy boiled meats. $8 \%$ can eat any type and $11 \%$ don't eat meat at all.

The effect of food habits and life style on general complains of liver, kidneys and GIT.

Comparison between boys and girls students according to general complains:

Pain is the main complaint of all students (Table 5); abdominal pain and kidney 
Thouraya Messallam Hassan, Mohamed Samir El-Dashlouty, and Mona Mohammad

Salama

pain included. $66.7 \%$ felt pain, $83 \%$ of girls and $50 \%$ of boys. $41.7 \%$ of students felt fatigued, $46.6 \%$ of boys and $36.6 \%$ of girls, i.e. the main complaint of boys was pain then fatigue. While the first complaint of girls was pain then fatigue. $10 \%$ of total students had repeated infection, $41.7 \%$ felt tired and fatigue, $66.7 \%$ had pain in their bodies, $5 \%$ had worms in stools (infestations), 5\% had anemia, $23 \%$ had no complain.

El Ansari et al., (2014) studied the most prominent complaints in Egypt and United Kingdom, and reported that university students generally report a wide range of symptoms and health complaints that can be broadly characterized into: (1) psychological health complaints; (2) circulatory and breathing symptoms; gastrointestinal symptoms; and, (4) pains and aches. Our study was in agreement with Saudi Arabia students as reported by Khan (2008), pain was most prominent complain. Equally in Netherlands as reported by
Bruls et al., (2013) and in Nigerian students as reported by Obembe et al., (2013).

Study also is in agreement with that of Norton et al., (1999) in Canada, who reported that $51.2 \%$ of university students were diagnosed as having gastrointestinal symptoms. Korean college students had a $5.7 \%$ prevalence of irritable bowel syndrome (Kim and Ban, 2005). Equally, in China, university students showed a $15.7 \%$ prevalence of irritable bowel syndrome where abdominal pain was a common symptom (Shen et al., 2009)

\section{Comparison between boys and girls students according to GIT symptoms:}

All students were given a questionnaire about gastrointestinal tract (GIT) considering symptoms they felt (Table6). $81.7 \%$ of all students had GIT symptoms, $83.4 \%$ of girls and $80 \%$ of boys

$28.3 \%$ had bloating after meals, $51.6 \%$ had abdominal pain $20 \%$ were better without 
The Effect of Dietary Habits and Lifestyle on Gastrointestinal, Liver, and Kidney Clinical Status in University Hostel Students

Thouraya Messallam Hassan, Mohamed Samir El-Dashlouty, and Mona Mohammad Salama

eating, 58.3 felt lethargy and laziness after eating, $15 \%$ had bad breath, $23.3 \%$ had abnormal stools (pale, dark, worms). $23.3 \%$ had foul gases. $13.3 \%$ had palpitations and breathlessness after eating, $26.6 \% \%$ had nausea. Girls are much higher and statistically different than boys concerning abnormal bowl movements and nausea. $18.3 \%$ of total had no GIT symptoms. Anyhow girls are suffering more than boys concerning GIT.

Our study went in agreement with Meng et al., (2014) who reported; in a study on college students in hostels; that the prevalence of dyspepsia (bad digestion with pain, bloating, nausea, heartburn, better without eating) was significantly higher in girls than in boys $(7.53 \%$ vs $4.14 \%, P<$ 0.05). Nearly all (95.37\%) students with dyspepsia reported symptoms of postprandial distress syndrome (pain, palpitation and breathlessness after eating), but only a small portion $(4.63 \%) \quad$ reported

symptoms suggestive of abdominal pain syndrome. The students with dyspepsia also showed significantly higher rates of spastic colon (16.67\%) and GERD (esophageal regurgitation) (11.11\%).

El Ansari et al., (2014) observed higher levels of psychological and gastrointestinal symptoms in females after their study with eleven faculties at the university of Assiut city, in Egypt

Also the high prevalence of female GIT symptoms in college students was in agreement with Haugland $\boldsymbol{e t}$ al., (2001) and Stock et al., (2003).

The present work agreed also with Niranjan et al.,(2016) in India concerning the high prevalence of GIT symptoms among hostel resident of a medical college $(63.17 \%)$. They added that it may be due to unhygienic mess condition or taking food mostly from outside. However disagreed with them in 
The Effect of Dietary Habits and Lifestyle on Gastrointestinal, Liver, and Kidney Clinical Status in University Hostel Students

Thouraya Messallam Hassan, Mohamed Samir El-Dashlouty, and Mona Mohammad Salama

the prevalence as in their study, the prevalence was more common $(69.10 \%)$ in hostels of boys than that of hostels of girls $(54.23 \%)$.

\section{Saad and Chey (2006)} reported that functional indigestion is estimated to affect about $15 \%$ of the general population in western countries.

\section{Percent distribution of studied} subjects (girls and boys) according to symptoms of food Allergy:

$36.7 \%$ of students had allergic symptoms (Table7). $13.3 \%$ showed breathlessness and palpitations after eating, $26.6 \%$ had nausea and $21.6 \%$ had abnormal bowl movements (diarrhea, constipation and alternation). $15 \%$ mentioned skin allergy and $63.3 \%$ were free.

Food allergy can be mild and can be fatal; therefore it took great care in different countries. In 2015, five students died at different states from food allergies in US and Canada.
Researchers estimate that up to 15 million Americans have food allergies including celiac disease; teenagers and young adults are at the highest risk for fatal food-induced anaphylaxis. Food allergy reactions send someone to the emergency department every three minutes, resulting in more than 200,000 emergency department visits in the U.S. per year. The U.S. Department of Justice and Lesley University agreed to list it as disability. And thus establishing a campus-wide approach, solid policies and procedures, and effective training are essential to providing a safe and inclusive environment (U.S. Department of Justice Civil Rights Division, 2014)

Eight foods are responsible for the majority of allergic reactions: Cow's milk, eggs, fish, peanuts, shellfish, soy, nuts and wheat (American Academy of Allergy, Asthma \& Immunology, 2016) 
The Effect of Dietary Habits and Lifestyle on Gastrointestinal, Liver, and Kidney

Clinical Status in University Hostel Students

Thouraya Messallam Hassan, Mohamed Samir El-Dashlouty, and Mona Mohammad

Salama

\section{Clinical examinations}

All students were clinically examined for signs concerning GIT, starting from mouth to bowl habits.

Comparison between boys and girls students according to presence of signs of mouth diseases:

Mouth - as being the first part of the gastrointestinal tract- was examined for redness, swelling, ulcers, whiteness, red tongue, red papillae, bleeding gum, abnormal teeth and caries (Table 8). 55\% had one or more symptom; $50 \%$ of girls and $60 \%$ of boys; the most prominent was bleeding gums followed by dental caries.

\section{Comparison between boys and} girls students according to presence of signs of GIT diseases:

Students were clinically examined for signs of GIT affection (Table8); distention, abdominal and loin tenderness, hepatomegaly or spleenomegaly and then asked in details for their bowl habits; diarrhea, constipation or alternating.

$71.6 \%$ of students had one or more GIT signs; $83.3 \%$ of girls and $60 \%$ of boys. This coincides with the symptoms they mentioned before $(81.7 \%$ of all students had GIT symptoms, $83.4 \%$ of girls and $80 \%$ of boys). This proves that these symptoms are real and that they are fully aware of it and call for an action to prevent or to ameliorate these symptoms through a suitable programs before starting residential life and to be followed all through the years of college.

\section{Biochemical examination}

Comparison between boys and girls students according to kidney function tests:

All students were tested for kidney affection on 6 levels:

- General complain as: kidney disease.

- Family history of kidney and gout . 
Thouraya Messallam Hassan, Mohamed Samir El-Dashlouty, and Mona Mohammad

Salama

- Symptoms as: Difficulty in urination, bone pain, loin pain

- Signs as: Loin tenderness.

- Nutritional evaluation : Excess red meat intake and junk food

- Laboratory test: urea, creatinine, uric acid.

All levels are within normal, however there was significant difference between boys and girls regarding urea $(19.0 \pm 2.9$ and $27.2 \pm 1.0)$ and creatinine $(1.1 \pm 0.1$ and $0.9 \pm 0.2 \mathrm{mg} / \mathrm{dl})$ respectively, boys had the highest normal level which may be a bad sign. Also there was significant difference between boys and girls in the urea level recording 19.0 \pm 2.9 and $\quad 27.2 \pm 1.0 \quad \mathrm{mg} / \mathrm{dl}$ respectively. Uric acid mean was $\quad 6.7 \pm 0.8$ with no significant differences. Uric acid is high for boys and girls, hyperuricemia was defined as serum uric acid level $>5.5 \mathrm{mg} / \mathrm{dL}$ (Kayadibi et. al.2014). Hyperuricemia is an independent risk factor for hypertension, and uric acid has pro-oxidant and proinflammatory effects. Adolescents with high serum uric acid levels may be at risk to develop hypertension, cardiovascular or renal disease later in their life. A correlation between uric acid in childhood and blood pressure was found in all race and sex groups except black males. Lowering serum uric acid should be made as early as possible, as once intra renal vascular changes occur; hypertension becomes more related to renal disease than uric acid (Khaled and Nevien 2015)

Hyperuricemia may explain some of the bone pains that are felt by most of students. It seems that the amount of fried meat that is eaten by students. The fast foods especially meat products may have caused this elevation which is hazardous for health.

Comparison between boys and girls students 
The Effect of Dietary Habits and Lifestyle on Gastrointestinal, Liver, and Kidney Clinical Status in University Hostel Students

Thouraya Messallam Hassan, Mohamed Samir El-Dashlouty, and Mona Mohammad

Salama

according to liver function tests:

All students were tested for liver affection on 6 levels

- General complain as: Hepatic disease.

- Family history of hepatic disease and virus $\mathrm{C}$.

- Symptoms as: Pain after eating, lethargy after eating, fatigue.

- Signs as: Yellowish skin and conjunctiva.

- Nutritional evaluation as: Excess intake of junk foods.

- Laboratory test: AST, ALT.

There was significant difference between boys and girls pertaining AST only, their values were $6.2 \pm 1.1$ and $4.0 \pm 0.8$ respectively, while the values for ALT were 4.1 \pm 1.4 and 4.9 \pm 2.1 respectively, being within normal.

Comparison between boys and girls students according to lipid profile:
Lipid profile lies within normal levels for boys and girls without significant differences. Although the students eat a lot fried food and junk food however the inheritance is the main reason for lipid abnormalities followed by diet. If the students continue to practice non healthy life style and saturated fats, lipids will eventually be elevated which may cause cardiovascular affection in their adult life.

Comparison between boys and girls students according to hemoglobin concentration

$\mathrm{Hb}$ levels show high levels in boys $(13.9 \pm 1.1)$ than girls $(11.8 \pm 1.0)$ which is significant.

Normal values for $\mathrm{Hgb}$ are:

$\mathrm{Hgb} \geq 19 \mathrm{yrs} / \mathrm{male} 14-18$ $\mathrm{g} / \mathrm{dL}$

$\mathrm{Hgb} \geq 19 \mathrm{yrs} /$ female 12 $16 \mathrm{~g} / \mathrm{dL}$

Data of values are normal for boys and slightly below normal for girls. The present study agrees with that conducted in Taibah University 
The Effect of Dietary Habits and Lifestyle on Gastrointestinal, Liver, and Kidney Clinical Status in University Hostel Students

Thouraya Messallam Hassan, Mohamed Samir El-Dashlouty, and Mona Mohammad

Salama

in Saudi Arabia which reported the prevalence of anemia to be (64\%) among female students (Nasir, 2015), and with another study in UAE which reported an overall prevalence of anemia ( $\mathrm{Hb}<12 \mathrm{~g} / \mathrm{dL}$ ) among female college students to be $26.7 \%$ and the majority $(88.4 \%)$ of the 69 anemic students had mild anemia, whereas $7.2 \%$ were moderately anemic and $2.3 \%$ were severely anemic (hemoglobin $<7 \mathrm{~g} / \mathrm{dL}$ ).

\section{Comparison between boys and} girls students according to random blood sugar:

$\mathrm{Hb}$ and random sugar were conducted to exclude some symptoms that may conflict them with food allergy e.g. tiredness, weakness, dizziness, irritability, shortness of breath.

\section{CONCLUSION}

\& RECOMMENDATIONS

College students in university hostels practiced unhealthy life style and food habits; $53 \%$ ate while watching
$\mathrm{TV}, 8 \%$ of boys are cigarette smokers, the frequency of sports per week was as low as 1.2 times only, $70 \%$ of students preferred junk foods and $45 \%$ of students preferred fried foods. These habits affected the GIT negatively as the most prevalent general complain were pains, food allergies and infestations. $81.7 \%$ of all students had GIT symptoms, $83.4 \%$ of girls and $80 \%$ of boys; $28.3 \%$ had bloating after meals, $51.6 \%$ had abdominal pain $20 \%$ were better without eating, 58.3 felt lethargy and laziness after eating, 15\% had bad breath, $23.3 \%$ had abnormal stools (pale, dark, worms). $23.3 \%$ had foul gases.

$36.7 \%$ of students had allergic symptoms; $13.3 \%$ showed breathlessness and palpitations after eating, 26.6\% had nausea and $21.6 \%$ had abnormal bowl movements (diarrhea, constipation and alternation), food allergy can pass mildly mostly but it can also be fatal. 
The Effect of Dietary Habits and Lifestyle on Gastrointestinal, Liver, and Kidney Clinical Status in University Hostel Students

Thouraya Messallam Hassan, Mohamed Samir El-Dashlouty, and Mona Mohammad Salama

The clinical examination confirmed the symptoms where $72 \%$ had GIT signs and 55\% had one or more mouth affection; the most prominent was bleeding gums followed by dental caries. Liver and kidneys were free clinically and had normal laboratory tests.

Educational programs should be held for all students in the first academic year to inform students about GIT problems, what to expect, how to prevent and how to seek help especially in critical cases like food allergy.

\section{REFERENCES}

\section{Abolfotouh MA; Bassiouni F; Mounir G and Fayyad R (2007): \\ Health-related lifestyles and risk behaviours among students living in Alexandria University hostels. Eastern Mediterranean Health J., 13: 376-391.}

Allain CC (1974):

Cholesterol enzymatic colorimetric method. $J$. of Clin. Chem., 20: 470.

American Academy of Allergy, Asthma \&Immunology. (2016):

Food allergy overview. 555 East Wells Street Suite 1100, Milwaukee, WI 53202-3823 (414) 272-6071.

http://www.aaaai.org

Aravind G; Mondal S; Gandhi $\mathrm{A}$; Arora $\mathrm{S}$ and Bhattacharjee J (2011): Effect of integrated yoga practices on immune responses in examination stress-A preliminary study. Int. J. Yoga, 4: 2632.

Artimage GY and Berry WG (1987):

Statistical Methods 7th Ed. Ames, Iowa State University Press, 39-63. 
The Effect of Dietary Habits and Lifestyle on Gastrointestinal, Liver, and Kidney

Clinical Status in University Hostel Students

Thouraya Messallam Hassan, Mohamed Samir El-Dashlouty, and Mona Mohammad

Salama

Bruls V; Bastiaenen C and de Bie R (2013):

Non-traumatic arm, neck and shoulder complaints: Prevalence, course and prognosis in a Dutch university population. BMC Musculoskelet. Disord., 4.

Campos D; Jose HernandezTorres, J; Agil, A; et al (2016):

Analysis of food advertising to children on Spanish television: probing exposure to television marketing. Archives of Medical Science, 12 (4):799-807

Carahera M; Lloydb S; Mansfieldc M; Alpc C; Brewsterc $Z$ and Greshamc J (2016):

Secondary school pupils' food choices around schools in a London borough: Fast food and walls of crisps. Appetite J., 103: 208-
220

Centers for Disease Control and Prevention (2015):

Current cigarette smoking among adultsUnited States, 20052014. Morbidity and Mortality Weekly Report, 64(44):1233-40

Dacie A and Lewis J (1998):

Practical Hematology. Churchill. Livingstone. Newyork.pp.50-65.

Doygun $O$ and Gulec $O$ (2012):

The problems faced by university students and proposals for solution. Proc. Social Behav. Sci., 47: 1115-1123.

El Ansari W; Reza O; Shokria $L$ and Christiane $S$ (2014):

Symptoms and health complaints and their association with perceived stress at university: survey of 
The Effect of Dietary Habits and Lifestyle on Gastrointestinal, Liver, and Kidney

Clinical Status in University Hostel Students

Thouraya Messallam Hassan, Mohamed Samir El-Dashlouty, and Mona Mohammad

Salama

students at eleven

faculties in Egypt. Cent.

Eur. J. Public Health, 22

(2): 68-79.

Elkhalifa A; Godbi S and Mohammed S (2000):

Nutrition assessment of students in university hostels. Ahfad J., 17: 3344.

Fossati $P$ and Prencipe $L$ (1982):

Triglyceride enzymatic colorimetric method. $J$. of Clin. Chem., 28:2077.

Friedewald WT; Levy RI and Fredrickson DS (1972):

Estimation of the concentration of lowdensity lipoprotein cholesterol in plasma, without use of the preparative

ultracentrifuge. Clin Chem. 18:499-502.
(2001):

Subjective health

complaints in

adolescence. A crossnational comparison of prevalence and dimensionality. Eur. J. Public Health, 11(1):410.

Henry R (1974):

Clinical Chemistry Principles and Techniques. Second ed. Harper and Ow; New York.

Huda N and Ruzita A (2011):

Preliminary survey on BMI profile among USM main campus students. Pak. J. Nutr., 9: 125-127.

Kaplan LA (1984):

Clinical Chemistry. The C.V.Mosby Co. St Louis. Toronto. Princeton, $P$. 1032-1036.

Kayadibi H; Sertoglu E and Uyanik M (2014):

Stevenson J; Aaroe L; Woynarowska 
The Effect of Dietary Habits and Lifestyle on Gastrointestinal, Liver, and Kidney Clinical Status in University Hostel Students

Thouraya Messallam Hassan, Mohamed Samir El-Dashlouty, and Mona Mohammad Salama

Importance of the selected cut-offs for serum uric acid and lipids levels. Scientific World J.;2014:746561.

Khan M (2008):

A dverse effects of excessive mobile phone use. Int. J. Occup. Med. Environ. Health, 21:289293.

\section{Kim Y and Ban D (2005):}

Prevalence of irritable bowel syndrome, influence of lifestyle factors and bowel habits in Korean college students. Int. J. Nurs. Stud., 42:247-254 .

Lopez MF (1977):

HDL - Cholesterol colorimetric method. $J$. of Clin. Chem., (23):882.

\section{Ma Y; Bertone E; Stanek E;} Reed $\mathrm{G}$ and Hebert $\mathrm{J}$ et al. (2003):
Association
between
eating patterns and obesity in a free-living US adult population. Am. J. Epidemiol., 158: 85- 92.

Malhotra V K (2003):

Practical Biochemistry for Students. Fourth Edition, Jaypee Brothers Medical Publishers (p) LTD, New Delhi.

\section{Marcel D (2016):}

A note on the meanings of junk food. Journal of the International Association for Semiotic Studies. 2016 (211): 4557

Memis E and Sanlier N (2010): Analysis of nutrition habits of the teachers and nurses. Pak. J. Nutr., 9: 1176-1182.

\section{Meng L; Bin L; Li C; Hong Z and Ming-Yan $C$} (2014):

Prevalence

and 
The Effect of Dietary Habits and Lifestyle on Gastrointestinal, Liver, and Kidney

Clinical Status in University Hostel Students

Thouraya Messallam Hassan, Mohamed Samir El-Dashlouty, and Mona Mohammad

Salama

characteristics of
dyspepsia among college
students in Zhejiang
Province. World J.
Gastroenterol., 20(13):
3649-3654.
Nasir N (2015):
The prevalence of iron
deficiency anemia in a
Saudi University female
students. Journal of
Microscopy and
Ultrastructure, Vol 3,
Issue 1, 25-28

National Sleep Foundation. (2015):
Central India,
International Journal of
Health Sciences and
Research (IJHSR), 6 (2):
30-36 .

Norton GR; Norton P; Asmundson G;

Thompson $L$ and

Larsen D (1999):

Neurotic butterflies in my stomach: The role of anxiety, anxiety sensitivity and depression in

functional gastrointestinal disorders. J. Psychosom. Res., 47:233-240.

Sleep Health: The Journal of the National Sleep Foundation, 1, (4): 233-243

Obembe A; Johnson O;
Tanimowo $\begin{aligned} & \text { T; } \\ & \text { Onigbinde A and } \\ & \text { Emechete A (2013): } \\ & \text { Musculoskeletal pain } \\ & \text { among undergraduate } \\ & \text { laptop users in a Nigerian } \\ & \text { University. J. Back } \\ & \text { Musculoskelet Rehabil., } \\ & \text { 26:389-395. }\end{aligned}$

Niranjan A; Adhikari P;

Mishra A; Saxena M;

Kumar $S$ and Kumar

$M$ (2016):

Prevalence

and

Determinants of Gastro-

\section{Saad R and Chey W (2006):}

Review article: current 
The Effect of Dietary Habits and Lifestyle on Gastrointestinal, Liver, and Kidney

Clinical Status in University Hostel Students

Thouraya Messallam Hassan, Mohamed Samir El-Dashlouty, and Mona Mohammad

Salama

and emerging therapies

for functional dyspepsia.

Aliment. Pharmacol.

Ther., 24 (3): 475-92.

Sanlier N and Unusan N (2007):

The relationship

between body weight and

stress and nutritional

status in Turkish women.

Pak. J. Nutr., 6: 339-344.

Scheibe P: Bernt E and Bergmeyer H U (1974):

Uric Acid, In Methods of Enzymatic Analysis

(Bergmeyer, H. U., ed.), Academic Press, New York, N. Y. pp 19511954.

\section{Shen L; Kong $\mathrm{H}$ and Hou $\mathrm{X}$} (2009):

Prevalence of irritable bowel syndrome and its relationship with psychological stress status in Chinese university students. $J$. Gastroenterol. Hepatol., 24:1885-1890.
Song WO; Chun O; Obayashi $\mathrm{S}$; Cho $\mathrm{S}$ and Chung $\mathrm{C}$ (2005):

Is consumption of breakfast associated with body mass index in US adults?. J. Am. Dietetic Assoc., 105: 1373-1382.

Stock C; Kücük N; Miseviciene I; GuillénGrima F; Petkeviciene, $\mathrm{J}$ and Aguinaga-Ontoso I (2003):

Differences in health complaints among university students from three European countries. Prev Med., 37(6 Pt 1):535-43.

Tietz NW (1976):

Fundamentals of Clinical Chemistry, 2nd ed., W. B. Saunders Company, Philadelphia, PA.

U.S. Department of Justice Civil Rights Division (2014): 
The Effect of Dietary Habits and Lifestyle on Gastrointestinal, Liver, and Kidney Clinical Status in University Hostel Students

Thouraya Messallam Hassan, Mohamed Samir El-Dashlouty, and Mona Mohammad Salama

Questions and Answers about the Lesley University Agreement and Potential Implications for Individuals with Food Allergies. Available at www.ada.gov/q\&a_lesley _university.htm.

USDL United States Dept. of Labor.(2016):

Bureau of Labor statistics. American Time Use Survey-2015 Results. Retrieved from http://www.bls.gov/news. release/pdf/atus.pdf

WHO (2016):
Fact sheet. Physical activity. Retrieved from http://www.who.int/medi acentre/factsheets/fs385/ en/lfactsheets/fs311/en/.

WHO (2011):

Obesity and Overweight. http://www.who.int/medi acentre

WHO (2007):

Growth reference 5-19 years. Retrieved from http://www.who.int/growt href/who2007_bmi_for_a gelen/.

Yound DS (1975): Determination of GOT $J$. Clin .Chem., 21:1. 
The Effect of Dietary Habits and Lifestyle on Gastrointestinal, Liver, and Kidney Clinical Status in University Hostel Students

Thouraya Messallam Hassan, Mohamed Samir El-Dashlouty, and Mona Mohammad

Salama

Table (1): Number and percent distribution of students by faculty and sex

\begin{tabular}{|l|l|l|l|l|}
\hline & Faculty: & $\begin{array}{l}\text { Boys } \\
\mathbf{N = 3 0}(\boldsymbol{\%})\end{array}$ & $\begin{array}{l}\text { Girls } \\
\mathbf{N}=\mathbf{3 0}(\boldsymbol{\%})\end{array}$ & $\begin{array}{l}\text { Total } \\
\mathbf{N = 6 0}(\%)\end{array}$ \\
\hline $\begin{array}{l}\text { Practical } \\
\text { Colleges }\end{array}$ & Medicine & $6(20.0)$ & 0 & $6(10.0)$ \\
& Engineering & $16(53.3)$ & 0 & $16(26.7)$ \\
& Home Economies & 0 & $25(83.3)$ & $25(41.7)$ \\
\hline Total & & $22(73.3)$ & $25(83.3)$ & $47(78.3)$ \\
\hline $\begin{array}{l}\text { Theoretical } \\
\text { Colleges }\end{array}$ & Lommerce & $3(10.0)$ & $1(3.3)$ & $4(6.6)$ \\
& Law & $1(3.3)$ & $2(6.7)$ & $3(5.0)$ \\
\hline Total & & $4(13.3)$ & $2(6.7)$ & $6(10.0)$ \\
& & $8(26.7)$ & $5(16.7)$ & $13(21.7)$ \\
\hline
\end{tabular}

Anthropometric measures and blood pressure

Table (2): Age, Heights, Weights and BMI of the students by sex

\begin{tabular}{|l|l|l|l|l|}
\hline & $\begin{array}{l}\text { Boys N=30 } \\
\text { Mean } \pm \text { SD }\end{array}$ & $\begin{array}{l}\text { Girls N=30 } \\
\text { Mean } \pm \text { SD }\end{array}$ & $\mathbf{p}$ & $\begin{array}{l}\text { Total N=60 } \\
\text { Mean } \pm \text { SD }\end{array}$ \\
\hline $\begin{array}{l}\text { Age } \\
(\text { years })\end{array}$ & $19.4 \pm 0.8$ & $18.4 \pm 1.4$ & $0.001^{* *}$ & $18.9 \pm 1.2$ \\
\hline Height $(\mathbf{c m s})$ & $177.3 \pm 5.6$ & $160.9 \pm 7.1$ & $<0.001^{* *}$ & $169.1 \pm 10.4$ \\
\hline $\begin{array}{l}\text { Weight } \\
(\mathbf{k g})\end{array}$ & $81.9 \pm 11.9$ & $65.2 \pm 13.5$ & $<0.001^{* *}$ & $73.6 \pm 15.2$ \\
\hline $\begin{array}{l}\text { BMI } \\
\left(\mathbf{k g} / \mathbf{m}^{2}\right)\end{array}$ & $26.0 \pm 3.2$ & $25.2 \pm 5.2$ & 0.501 & $25.6 \pm 4.3$ \\
\hline
\end{tabular}


The Effect of Dietary Habits and Lifestyle on Gastrointestinal, Liver, and Kidney Clinical Status in University Hostel Students

Thouraya Messallam Hassan, Mohamed Samir El-Dashlouty, and Mona Mohammad Salama

Table (3): Mean and standard deviation of studied subjects (girls and boys) according to life style

\begin{tabular}{|c|c|c|c|c|c|}
\hline & & $\begin{array}{l}\text { Boys } \\
\mathrm{N}=30(\%)\end{array}$ & $\begin{array}{l}\text { Girls } \\
\mathrm{N}=30(\%)\end{array}$ & $\mathrm{P}$ & $\begin{array}{l}\text { Total } \\
\mathrm{N}=60(\%)\end{array}$ \\
\hline $\begin{array}{l}\text { Sports } \\
\text { practice }\end{array}$ & $\begin{array}{l}\text { No } \\
\text { Yes }\end{array}$ & $\begin{array}{l}11(36.7) \% \\
19(63.3) \%\end{array}$ & $\begin{array}{l}21(70.0) \\
9(30.0)\end{array}$ & $\begin{array}{l}0.01 * \\
0.25 \\
(0.08-0.7)\end{array}$ & $\begin{array}{l}32(52.5) \\
28(45.9)\end{array}$ \\
\hline $\begin{array}{l}\text { Eating } \\
\text { while } \\
\text { watching } \\
\text { TV }\end{array}$ & $\begin{array}{l}\text { No } \\
\text { Yes }\end{array}$ & $\begin{array}{l}14(46.7) \\
16(53.3)\end{array}$ & $\begin{array}{l}12(40.0) \\
18(60.0)\end{array}$ & $\begin{array}{l}0.602 \\
1.3 \\
(0.5-3.7)\end{array}$ & $\begin{array}{l}26(42.6) \\
34(55.7)\end{array}$ \\
\hline $\begin{array}{l}\text { Cig. } \\
\text { Smoking }\end{array}$ & $\begin{array}{l}\text { No } \\
\text { Yes }\end{array}$ & $\begin{array}{l}22(73.3) \\
8(26.7)\end{array}$ & $\begin{array}{l}30(100.0) \\
0\end{array}$ & $0.002 *$ & $\begin{array}{l}52(85.2) \\
8(13.1)\end{array}$ \\
\hline & & $\begin{array}{l}\text { Boys Mean } \\
\pm \text { SD }\end{array}$ & $\begin{array}{l}\text { Girls Mean } \\
\pm \text { SD }\end{array}$ & $\mathrm{P}$ & $\begin{array}{l}\text { Total Mean } \\
\pm \text { SD }\end{array}$ \\
\hline $\begin{array}{l}\text { Sleeping } \\
\text { hours/day }\end{array}$ & & $7.5 \pm 1.3$ & $7.3 \pm 1.6$ & 0.594 & $7.4 \pm 1.4$ \\
\hline $\begin{array}{l}\text { Sports } \\
\text { No. /week }\end{array}$ & & $1.2 \pm 1.2$ & $1.2 \pm 2.3$ & 0.837 & $1.2 \pm 1.9$ \\
\hline $\begin{array}{l}\text { TV } \\
\text { hours/day }\end{array}$ & & $1.7 \pm 1.4$ & $2.0 \pm 1.6$ & 0.448 & $1.9 \pm 1.5$ \\
\hline $\begin{array}{l}\text { No of } \\
\text { cig./day }\end{array}$ & & $3.2 \pm 8.1$ & 0 & $0.038 *$ & $1.6 \pm 5.9$ \\
\hline
\end{tabular}


The Effect of Dietary Habits and Lifestyle on Gastrointestinal, Liver, and Kidney Clinical Status in University Hostel Students

Thouraya Messallam Hassan, Mohamed Samir El-Dashlouty, and Mona Mohammad Salama

Table (4): Comparison between boys and girls students according to eating fast foods:

\begin{tabular}{|c|l|l|l|l|l|}
\hline \multicolumn{2}{|c|}{} & Boys N=30(\%) & Girls N=30(\%) & P & $\begin{array}{l}\text { Total N=60 } \\
(\%)\end{array}$ \\
\hline $\begin{array}{l}\text { Fast } \\
\text { food }\end{array}$ & No & $6(20)$ & $12(40)$ & 0.091 & $18(30)$ \\
\cline { 2 - 6 } & Yes & $24(80)$ & $18(60)$ & 0.17 & $42(70)$ \\
\hline \multirow{2}{*}{$\begin{array}{c}\text { Fast food } \\
\text { no./week }\end{array}$} & Mean \pm SD & Mean \pm SD & & Mean \pm SD \\
\cline { 2 - 6 } & $3.3 \pm 5.2$ & $1.7 \pm 2.0$ & 0.12 & $2.25 \pm 3.2$ \\
\hline
\end{tabular}

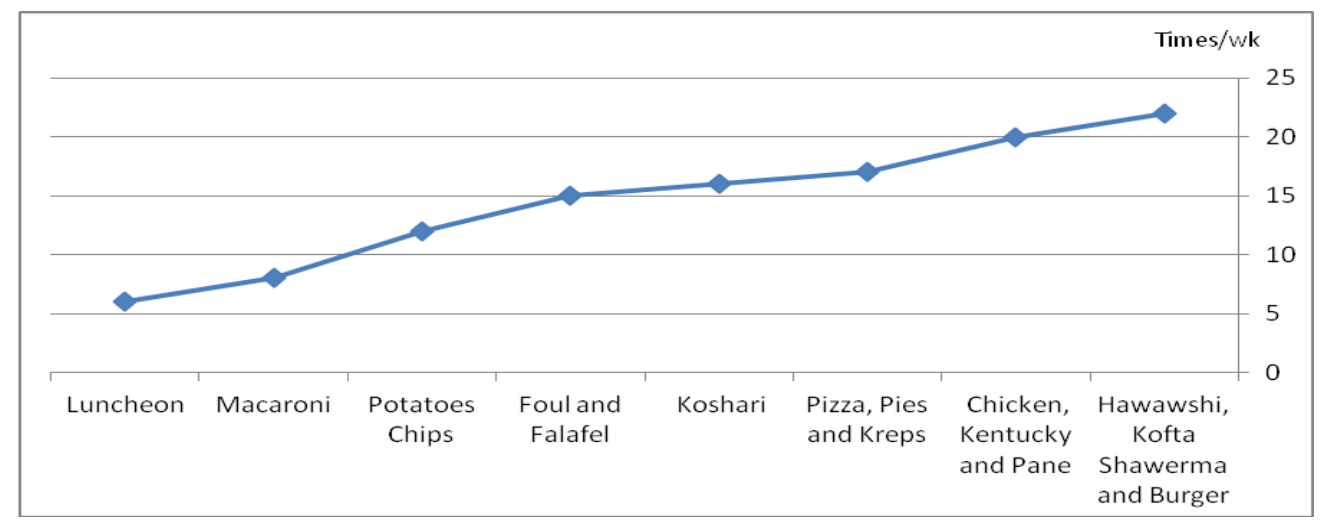

Fig (1): Comparison between fast foods consumption per week. 
The Effect of Dietary Habits and Lifestyle on Gastrointestinal, Liver, and Kidney Clinical Status in University Hostel Students

Thouraya Messallam Hassan, Mohamed Samir El-Dashlouty, and Mona Mohammad Salama

Table (5): Comparison between boys and girls students according to general complaints

\begin{tabular}{|l|l|l|l|}
\hline General complain & $\begin{array}{l}\text { Boys } \\
\mathbf{N = 3 0}(\%)\end{array}$ & $\begin{array}{l}\text { Girls } \\
\mathbf{N = 3 0}(\%)\end{array}$ & $\begin{array}{l}\text { Total } \\
\mathbf{N = 6 0}(\%)\end{array}$ \\
\hline Recurrent infection & $3(10)$ & $3(10)$ & $6(10)$ \\
\hline Fatigue & $14(46.6)$ & $11(36.6)$ & $25(41.7)$ \\
\hline Pain & $15(50)$ & $25(83.3)$ & $40(66.7)$ \\
\hline Infestations & $2(6.6)$ & $1(3.3)$ & $3(5)$ \\
\hline Anemia & $1(3.3)$ & $2(6.6)$ & $3(5)$ \\
\hline $\begin{array}{l}\text { Others (Bleeding gum, gastritis, } \\
\text { virus C) }\end{array}$ & $1(3.3)$ & $1(3.3)$ & $2(3.3)$ \\
\hline Non & & & \\
\hline & $10(33.3)$ & $4(13.3)$ & $14(23.3)$ \\
\hline
\end{tabular}

Table (6): Comparison between boys and girls students according to GIT symptoms

\begin{tabular}{|l|l|l|l|l|}
\hline GIT SYMPTOMS & $\begin{array}{l}\text { Boys N=30 } \\
(\boldsymbol{\%})\end{array}$ & $\begin{array}{l}\text { Girls } \\
\mathbf{N = 3 0}(\boldsymbol{\%})\end{array}$ & $\mathbf{P}$ & $\begin{array}{l}\text { Total } \\
\mathbf{N = 6 0} \\
(\boldsymbol{\%})\end{array}$ \\
\hline Bloating after meals & $6(20)$ & $11(36.6)$ & 0.1481 & $17(28.3)$ \\
Pain(s) & $12(40)$ & $19(63.3)$ & 0.0772 & $31(51.6)$ \\
Better without food & $5(16.6)$ & $7(23.3)$ & 0.5646 & $12(20)$ \\
Lethargy after eating & $17(56.6)$ & $18(60)$ & 0.8151 & $35(58.3)$ \\
Bad breath & $6(20)$ & $3(10)$ & 0.2821 & $9(15)$ \\
Abnormal stool & $5(16.6)$ & $9(30)$ & 0.2390 & $14(23.3)$ \\
Abnormal bowl & $3(10)$ & $10(33.3)$ & $0.0315^{*}$ & $13(21.6)$ \\
Foul gases & $4(13.3)$ & $1(3.3)$ & 0.1569 & $5(23.3)$ \\
Palpitation, & $2(6.6)$ & $6(20)$ & 0.1099 & $8(13.3)$ \\
breathless after eating & $3(10)$ & $13(43.3)$ & $0.004 * *$ & $16(26.6)$ \\
Nausea & $24(80)$ & $25(83.4)$ & 0.6893 & $49(81.7)$ \\
Total & $6(20)$ & $5(16.6)$ & 0.6893 & $11(18.3)$ \\
Non & & & & \\
\hline
\end{tabular}


The Effect of Dietary Habits and Lifestyle on Gastrointestinal, Liver, and Kidney Clinical Status in University Hostel Students

Thouraya Messallam Hassan, Mohamed Samir El-Dashlouty, and Mona Mohammad Salama

Table (7): Percent distribution of total subjects (girls and boys) according to allergy symptoms

\begin{tabular}{|l|l|}
\hline Allergies symptoms & $\begin{array}{l}\text { Total N=60 } \\
\text { No. }(\%)\end{array}$ \\
\hline Breathlessness and palpitations after eating & $8(13.3)$ \\
Nausea & $16(26.6)$ \\
Abnormal bowl & $13(21.6)$ \\
Recurrent skin allergy & $9(15)$ \\
Non & $38(63.3)$ \\
\hline
\end{tabular}

Table (8): Comparison between boys and girls students according to presence of signs of signs of mouth and GIT diseases

\begin{tabular}{|l|l|l|l|l|l|}
\hline Signs & $\begin{array}{l}\text { Boys } \\
\mathbf{N = 3 0}(\%)\end{array}$ & $\begin{array}{l}\text { Girls } \\
\mathbf{N = 3 0}(\%)\end{array}$ & P OR (CI) & $\begin{array}{l}\text { TotalN=6 } \\
\mathbf{0}(\%)\end{array}$ \\
\hline Mouth & Yes & $18(60)$ & $15(50)$ & 0.436 & $33(55)$ \\
\hline GIT & No & 12 & 5 & $0.045^{*}$ & 17 \\
& Yes & $18(60)$ & $25(83.3)$ & $3.3(1.0-11.1)$ & $43(71.6)$ \\
\hline
\end{tabular}


The Effect of Dietary Habits and Lifestyle on Gastrointestinal, Liver, and Kidney Clinical Status in University Hostel Students

Thouraya Messallam Hassan, Mohamed Samir El-Dashlouty, and Mona Mohammad Salama

Table (9): Comparison between boys and girls students according to kidney function tests, liver function tests, lipid profile, hemoglobin and random blood sugar

\begin{tabular}{|c|c|c|c|c|c|}
\hline & & $\begin{array}{l}\text { Boys } \\
\text { Mean } \quad \pm \\
\text { SD }\end{array}$ & $\begin{array}{l}\text { Girls } \\
\text { Mean } \quad \pm \\
\text { SD }\end{array}$ & $\mathbf{p}$ & $\begin{array}{l}\text { Total } \\
\text { Mean } \pm \text { SD }\end{array}$ \\
\hline \multirow{3}{*}{$\begin{array}{l}\text { kidney } \\
\text { function } \\
\text { tests }\end{array}$} & $\begin{array}{l}\text { Creatinine } \\
\mathrm{mg} / \mathrm{dl}\end{array}$ & $1.1 \pm 0.1$ & $0.9 \pm 0.2$ & $<0.001 * *$ & $1.03 \pm 0.2$ \\
\hline & $\begin{array}{l}\text { Urea } \\
\mathrm{mg} / \mathrm{dl}\end{array}$ & $19.0 \pm 2.9$ & $27.2 \pm 1.0$ & $<0.001 * *$ & $23.1 \pm 4.7$ \\
\hline & $\begin{array}{l}\text { Uric acid } \\
\mathrm{mg} / \mathrm{dl}\end{array}$ & $6.6 \pm 1.1$ & $6.8 \pm 0.4$ & 0.241 & $6.7 \pm 0.8$ \\
\hline \multirow{2}{*}{$\begin{array}{c}\text { liver } \\
\text { function } \\
\text { tests }\end{array}$} & $\begin{array}{l}\text { ALT } \\
\text { U/I }\end{array}$ & $4.1 \pm 1.4$ & $4.9 \pm 2.1$ & 0.083 & $4.5 \pm 1.8$ \\
\hline & $\begin{array}{l}\text { AST } \\
\text { U/I }\end{array}$ & $6.2 \pm 1.1$ & $4.0 \pm 0.8$ & $<0.001 * *$ & $5.1 \pm 1.4$ \\
\hline \multirow{4}{*}{$\begin{array}{c}\text { lipid } \\
\text { profile } \\
\text { mg/dl }\end{array}$} & $\begin{array}{l}\text { Cholesterol } \\
\mathrm{mg} / \mathrm{dl}\end{array}$ & $\begin{array}{l}170.2 \pm 30 \text {. } \\
7\end{array}$ & $\begin{array}{l}168.4 \pm 31 \\
6\end{array}$ & 0.83 & $169.3 \pm 30.9$ \\
\hline & $\begin{array}{l}\mathrm{TG} \\
\mathrm{mg} / \mathrm{dl}\end{array}$ & $\begin{array}{l}125.7 \pm 42 . \\
9\end{array}$ & $\begin{array}{l}111.6 \pm 55 \\
5\end{array}$ & 0.275 & $118.7 \pm 49.7$ \\
\hline & $\begin{array}{l}\text { HDL } \\
\mathrm{mg} / \mathrm{dl}\end{array}$ & $62.2 \pm 19.1$ & $56.4 \pm 13.3$ & 0.181 & $59.3 \pm 16.6$ \\
\hline & $\begin{array}{l}\mathrm{LDL} \\
\mathrm{mg} / \mathrm{dl}\end{array}$ & $82.9 \pm 33.4$ & $89.7 \pm 29.1$ & 0.402 & $86.3 \pm 31.3$ \\
\hline $\mathbf{H b}$ & $\begin{array}{l}\mathrm{Hb} \\
(\mathrm{g} / \mathrm{dl})\end{array}$ & $13.9 \pm 1.1$ & $11.8 \pm 1.0$ & $<0.001^{* * *}$ & $12.9 \pm 1.5$ \\
\hline Glucose & $\begin{array}{l}\text { Random } \\
\text { sugar mg/dl }\end{array}$ & $90.8 \pm 9.7$ & $88.2 \pm 8.9$ & 0.271 & $89.5 \pm 9.3$ \\
\hline
\end{tabular}


Thouraya Messallam Hassan, Mohamed Samir El-Dashlouty, and Mona Mohammad

\section{مدى تأثير العادات الغذائية ونمط الحياة على الجهاز

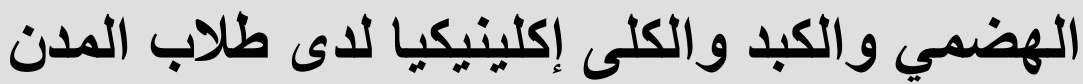 الجامعية}

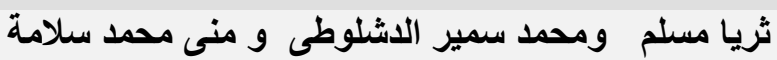

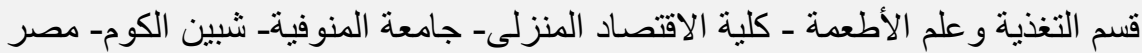

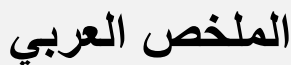

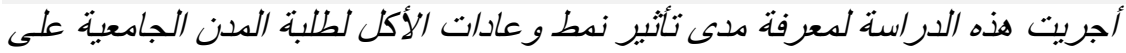

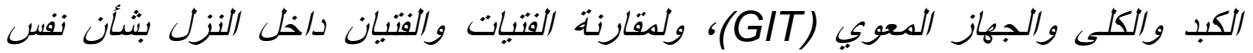

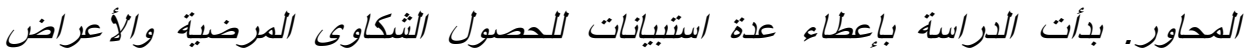

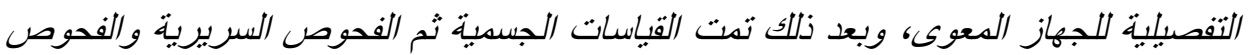

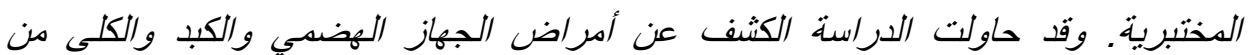

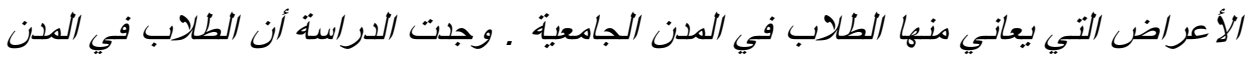

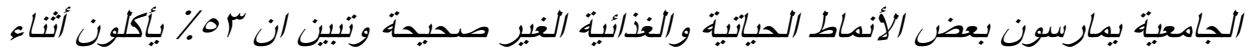

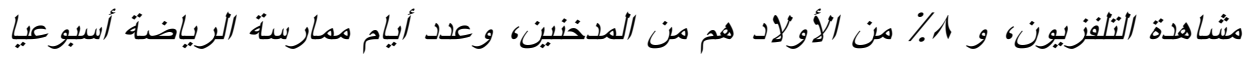

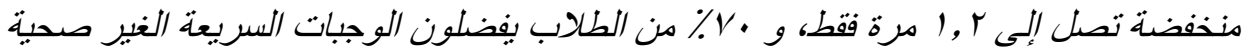

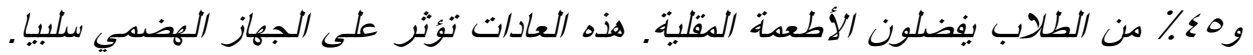

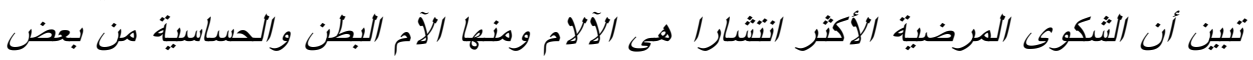

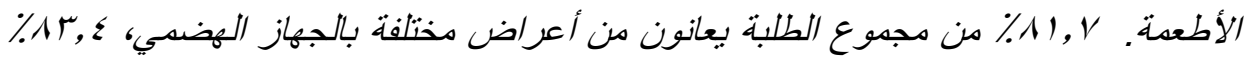

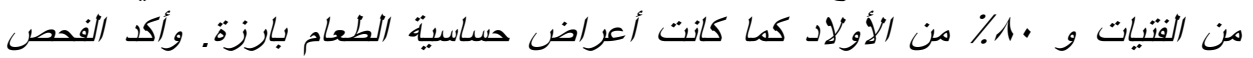

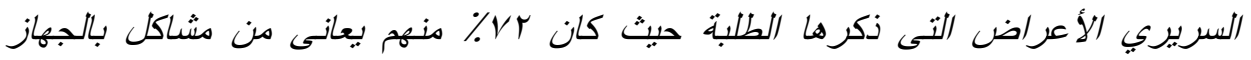

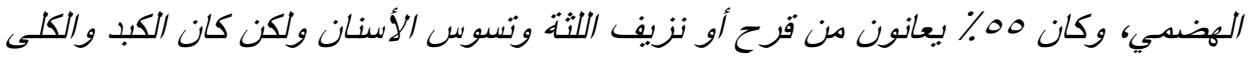
سليها إكلينيكيا ، وكانت الاختبارات الدعلية طبيعية.

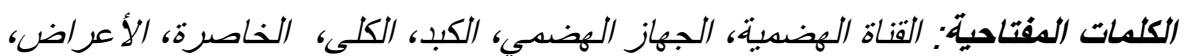

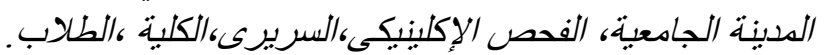

